\title{
An Evaluation of Critical Factors Impeding Performance of State Financed Road Construction Projects in Botswana
}

\author{
Otsile Morake * \\ School of Management, Jiangsu University, 301 Xuefu Rd, Zhenjiang, Jiangsu, 212013 P.R. China \\ Qing Feng Meng \\ School of Management, Jiangsu University, 301 Xuefu Rd, Zhenjiang, Jiangsu, 212013 P.R. China
}

\begin{abstract}
The study tried to evaluate the critical factors that impede the quality performance of state financed road construction projects in Botswana. There have been variations on completion time, cost and quality of state financed construction projects in Botswana and other developing countries. The study therefore classified factors that are thought to lead to poor quality performance of road construction projects. A questionnaire consisting of 15 quality performance factors were distributed to 120 participants with construction associated background, they were mandated to rank their responses on a 5-point Likert scale. The data was analyzed via the Statistical Package for Social Sciences (SPSS) version 23. It was discovered from the results that the five major critical factors that have direct impediments on quality performance of state financed road construction projects are; financing processes of the project, issues on health and safety, project managers skills and knowledge, profitability of contractors, and experiences of the contractor in the industry. The results also showed that project quality performance had a positive linear relationship with the critical quality performance factors from the developed multiple regression model. All the five major critical quality performance factors were significant and had positive coefficients.
\end{abstract}

Keywords: Project performance, Quality performance factors, Contractor's challenges, Government projects, Construction projects

DOI: $10.7176 / \mathrm{JESD} / 11-8-11$

Publication date: April $30^{\text {th }} 2020$

\section{Introduction}

One of the most important industries in any economy is the construction industry. The industry networks with nearly all areas of human activities. Regrettably, the inherent difficulty, uncertainty and changing aspects of most construction projects create hitches for even the best project managers(Ngwai, Simba, \& Oyoo, 2019). To anticipate outcomes, decision milestones are used, whiles risk management is done to thwart disasters. To also ensure that the desired facilities are available the successive iterations are employed, yet projects still face challenges, hence, end up with delays in schedules, overruns in the budget and compromised specifications that all end up in impeding the quality performance of the projects (Siati, Nzulwa, \& Kwena, 2019). Therefore, the task of handling a successful construction project has drawn considerable research consideration in the preceding couple of decades.

Road construction is carried out using modern materials, innovative designs, and methods in construction technology (Naoum \& Egbu, 2016). To be able to provide the high-quality road surface, it is apposite to espouse modern technologies in the field of road construction which can guarantee road traffic safety. In addition, it can also aid in attaining better economic benefits such as road life span and the reduction in road repairs and reconstruction(Alamgir et al., 2017).

According to literature, the management of construction projects requires knowledge of modern management as well as understanding of the design and the construction process (Rumane, 2017). Construction projects have a specific set of objectives and constraints such as a required time frame for completion. Also, they also employ so many personalities which makes it expensive, hence, in trying to decrease the cost, the project is affected. The changes that occurs due to cost in the construction industry affects majority of state projects, therefore fail to meet deadlines, cost and quality targets(Davis, 2017).

A number of states financed road construction projects have failed to successfully accomplish quality performance in Botswana(Fagbenle et al., 2018). Many state financed projects been handed over without achieving the quality performance requirements (Kerzner, 2019). There have been inadequate investigations on the factors impeding quality performance of state financed construction projects in Botswana. The reasons for this have generally been due to unqualified technical personnel for design and supervision of works, lack of competent, experienced and qualified contractors, and lack of appropriate equipment and availability of adequate funds (Santoso \& Soeng, 2016). This paper presents an evaluation of critical factors impeding quality performance of state financed construction projects in Botswana whereby if not considered carefully can lead to comparatively intolerable quality performance of projects in Botswana. 
Botswana, officially the Republic of Botswana, is a landlocked country in Southern Africa covering an area of $582000 \mathrm{sq}$. km. It has an estimated population of 2.8 million people. Botswana is a former British territory of Bechuanaland, from where it adopted its current name after becoming independent on 30 September 1966within the Commonwealth. It has since been a republic nation, with an envious record of continuous democratic elections making it Africa's oldest continuous democracy and the best perceived corruption ranking in Africa since 1998. It has an average annual GDP growth rate of 13 percent. The country is highly recognized for its rich mineral deposits, as in high-quality diamonds. Though the construction industry growth is at its infancy, the Government of Botswana views the construction industry as an important engine of economic growth.

\section{Literature Review}

Project quality performance (PQP)also termed as project success has been lengthily researched by several researchers in the field of project management. According to Project Management Institute Guide Book (2004), the accomplishment of projects had been measured via timely delivery, on cost and parameters of targeted quality.

The quality performance has evolved from the Dark Age period, where the quality item responsibilities rested on craftsmen(Ugo, 2017). It was the responsibility of craftsmen for design, tools, sales and customers feedback. Quality performance of items hinge on craftsmen's skills which was constantly improving via replication of crafting comparable products. The success performance shifted emphasis from the craftsmen to the process. The current theories of quality performances concentrate on understanding of customer requirements (Lishner \& Shtub, 2019).

There are a number of preceding research works that had tried to establish the list of construction project success factors that can be appropriated to all projects, however researchers(Dong, Zhang, \& Lv, 2016; Kumar, Duhan, \& Haleem, 2016; Raphael \& Phillip, 2016), have contended that each construction project have specific needs and hence specific success performance factors. Project success performance in the construction industry could be sufficiently linked to attaining goals and objectives in time and at stated costs as well meeting or exceeding the customers/stakeholders' requirements or expectations.

Notwithstanding the huge inconsistency in the project success factors in construction, efforts had been made to advance analytical models (Jin, 2018; Osei-Kyei, Chan, Javed, \& Ameyaw, 2017), that if only critical factors are accepted there could be a precise model that can be used to forecast if the project will be or had been successful. Application of such models however has not been widely recognized as the so-called critical success factors do keep on changing for different projects.

Sfakianaki (2019)studied on 'critical success factors' across 63 publications and recognized more than twenty factors which has an influence on project success. Similarly, the frame work as suggested by Heravi and Mohammadian (2019)largely classified success factors as project efficiency, impact on customer, business success and preparing for the future. However, itis difficult to achieve all the set criteria in any given project. There are also some reproaches on the ideas of success factors. Chen, Chen, and Lin (2016)posits that there are disagreements of success concept, also, Padalkar and Gopinath (2016)claim that "project success is a multifaceted and equivocal concept and it changes over the project and product life cycle". Nevertheless, in-spite of the uncertainty, its continued significance in terms of goals is extensively accepted by industry and academia. According to, success factors in $21^{\text {st }}$ century are more about reasonable agreement before commencement of the project.

Mishmish and El-Sayegh (2018)studied the reasons for delay in the building projects of the UAE where their study found that the top five critical factors causing delay were: (1) drawing preparation and approval; (2) poor planning; (3) lack of rapid decision making from the owner; (4) lack of manpower; and (5) lack of proper supervision and management. Similarly, Al-Hazim, Salem, and Ahmad (2017)delineated five major factors causing delays in the Jordanian construction industry. They were: financial difficulties faced by the contractors; many changes in orders from the client; poor planning and scheduling by the contractor; unskilled labor; and a shortage of technical and skilled professionals.

On the other hand, Abdalla and Otieno (2017),noted that management in construction, has always been founded on experience and organizational talent. In most of the construction projects, technicalities are ceased during design stage. Abdalla and Otieno (2017)indicated that the vital category in constructions is construction firm i.e., the contractor since, the contractor is the one that gives physical shape to the product following the design. Therefore, the main subject lies in managing resources, material, equipment, stakeholders effectively by the contractor.

The assertion of Rahmani, Maqsood, and Khalfan (2017), suggest that the main contractor is employed to build what designers have specified and contracting was a response to the sophistication of industrialization(Akali $\&$ Sakaja, 2018). Also, the issues such as economies of scale, employment, multiple use of plant are some problems which made "contracting business popular and viable.

Therefore, in view of the above this study was put forward to have an opportunity of determining specific and critical success factors affecting quality performance of construction projects being executed in Botswana. 


\section{Research Methodology}

The aim of this study is to identify the critical factors that impede the quality performance of state financed construction project in Botswana. Grounding on literature review and field discussions with experienced practitioners in the road constructions industry, a list of 15 quality performance factors was established. The primary data were collected from target groups of contractors, engineers, owners and supervisors working in road construction projects. The stratified sampling method was used to identify a group of participants from the population and thereafter a simple sampling method was applied while distributing questionnaires to respondents. Close-ended questionnaire consisting of 15 quality performance factors were distributed to 120 respondents involved in road construction related activities, they were mandated to rank them on a 5 point Likert scale ranging from; not critical (1), slightly critical (2), critical (3), extensively critical (4) and highly critical (5). The quality performance factors that were considered were those which could have some impact on quality performance of road construction projects.

The Statistical Package for Social Sciences (SPSS) version 23 was used to analyze the data that were collected. The technique was selected because it has been extensively used in the preceding studies. The Kendall's tau correlation coefficients were applied to confirm data agreements for engineers, contractors, owners and supervisors. Moreover, in reference to the empirical literature review, the study considered an existence of a linear relationship between the project quality performance (dependent variable) and the critical factors (independent variables). The relationship assumed to be in the form of a multiple linear model. Collected data were tested on concurrence with the assumptions that reinforce the multiple linear regression models. Finally, the model itself was established.

\section{Research Analysis}

\subsection{Validity and reliability}

Validity test confirms what was purported to be measured. Reliability is the measure of homogeneousness in the test results. Cronbach's Alpha was espoused to test the reliability in data. Validity of data, was guaranteed by use of closed end questionnaires. The Cronbach's Alpha obtained was 0.895. Vaske, Beaman, and Sponarski (2017) noted that the accepted figure for reliability is $0.7-0.8$ for basic social sciences studies, therefore suggesting that the collected data is reliable.

\subsection{Descriptive Statistics}

The SPSS tool was used to ascertain respondents' sex, age, educational qualification, their positions and number of years in the construction industry. Under gender, the males dominated with 77 (64\%) of the respondents being males and $43(36 \%)$ being females, suggesting a male dominated field.

The age was divided into five (5) groups; being 21 to 34 years $(20 \%), 35$ to 44 years $(13 \%), 45$ to 54 years $(51 \%), 55$ to 65 year $(10 \%)$ and above 65 years $(6 \%)$. Majority of the respondents were aged above 44 years. This could as a result of the long training period prospective engineers are required to go thorough before qualify to be certified engineers. It also suggests that contractors need to be financially sound before starting such businesses, hence, limiting the number of young individuals venturing into that field.

The respondent's level of education was assessed to find out their suitability in the study. Analysis of the data shows that 11 (9\%) had no formal education, 23 (19\%) had primary education, 14 (12\%) had high/secondary school education, 20 (17) had some sort of training in the form of diploma and certificate training, $37(31 \%)$ had bachelor degree and $15(13 \%)$ had post graduate qualifications. Majority of the respondent were deemed qualified for the study and were seen to have the necessary knowledge in understanding the questionnaire.

The positions of the respondent were evenly distributed, hence, questionnaires targeted, 30 engineers, 30 contractors, 30, owners and 30 supervisors.

Working experience in construction industry is a significant commodity for anybody to be able to recognize important problems that could influence quality performance of contraction projects. Respondents with less than 6 years were 19 were $16 \%$, respondents with experiences between 6 to 8 years were 23 were $19 \%$, those with 9 to 11 years 42 were $35 \%$ and respondents with experiences above 12 years were $36 \%$. In summary well over $50 \%$ of respondents had adequate experience (over 10 years) in construction industry. Oke, Aigbavboa, and Dlamini (2017)made use of a comparable group of professionals encompassing of experienced owners, project consultants and contractors. Hence, the selected respondents for this study were regarded to be suitable.

\subsection{ParticipantsOpinions on Factors Affecting Quality Performance of Projects}

Applying the SPSS tool, the frequencies and percentages of each quality performance factor was determined. Table 1 presents the analyzed data on ranking of factors investigated in the study. The table shows that all the factors considered in this study were rated to be important. 
Table 1: Participants views on factors affecting quality performance of projects

\begin{tabular}{llll}
\hline Rank & Factors & Frequencies & Percentage \\
\hline 1 & Financing processes of the project & 21 & 17 \\
2 & Issues on health and safety & 14 & 12 \\
3 & Project managers skills and knowledge & 12 & 10 \\
4 & Profitability of contractors & 11 & 9 \\
5 & Experiences of the contractor in the industry & 10 & 8 \\
6 & Availability of construction materials & 8 & 7 \\
7 & Project team members' performance & 7 & 6 \\
7 & Local community involvement & 7 & 6 \\
9 & Variation in climate conditions & 6 & 5 \\
10 & Procurement system and processes & 5 & 4 \\
10 & Requirements of project technology & 5 & 4 \\
12 & Explicit technical specifications & 4 & 3 \\
12 & Supervision team skills and knowledge & 4 & 3 \\
14 & We inspire employees to make decision in innovation & 3 & 3 \\
14 & Construction equipment and spare parts availability & 3 & 3 \\
& Total & $\mathbf{1 2 0}$ & $\mathbf{1 0 0}$ \\
\hline
\end{tabular}

Source: Authors own compilation

The respondence opinion suggest that all project will be executed smoothly when the financing processes of the project is distinct from the start which conforms with the observation of Nasaruddin and Rahman (2017). Financing of project denotes to "Assurance" from the state or the financier of the said project. The other highly ranked quality performance factors were issues on health and safety, project managers skills and knowledge, profitability of contractors, experiences of the contractor in the industry contractor's, availability of construction materials, project team members' performance and local community involvement. As earlier noted by Nasaruddin and Rahman (2017)all these factors constitute a "Competence" critical success factor. Competence indicates that project respondents have satisfactory skills and experience, proficient enough to utilize up to-date technology for equipment, materials and the project itself.

According to Olawumi and Chan (2019), Project success hinge on the technical knowledge of respondents, who must be proficient in using up to-date technology for equipment, materials and the project itself as noted in this study.

This study also determined if individual groups of professionals (engineers, contractors, owners and supervisors) would have comparable ranking of the quality performance factors. The engineering group indicated that the five (5) highly ranked quality performance factors (with their percentages in brackets) were; financing processes of the project $(12.5 \%)$, project manager's skills and knowledge $(12.5 \%)$, variation in climate conditions (11\%), profitability of the contractors (10\%) and availability of construction materials (10\%).

Contractor's top five ranking included financing processes of the project (18.3\%), issues on health and safety $(14.2 \%)$, profitability of the contractors $(10 \%)$, project manager's skills and knowledge $(10 \%)$ and experiences of the contractor in the industry $(7.5 \%)$.

Owners top five ranking consisted of financing processes of the project (19.2\%), issues on health and safety $(11.7 \%)$, profitability of the contractors $(10 \%)$, project manager's skills and knowledge $(9.2 \%)$ and project team members performance $(9.2 \%)$

Supervisors top five ranking entailed, financing processes of the project $(16.7 \%)$, experiences of the contractor in the industry $(11.7 \%)$, issues on health and safety $(10.8 \%)$, profitability of the contractors $(10 \%)$ and project manager's skills and knowledge (10\%).

\subsection{Groups Views' Correlations on Quality Performance Factors}

Additional study was made on the relationship that exist between the opinions of different groups of engineers, contractors, owners and supervisors. The null hypothesis $\left(\mathrm{H}_{0}\right)$ tested suggested that "there exist no significant link between the opinions of different groups of professionals in respect to the relative importance of the quality performance factors". On the other hand, the alternative hypothesis $\left(\mathrm{H}_{1}\right)$ suggested that "there is significant link between the opinions of different groups of professionals in respect to the relative importance of the quality performance factors". Analytically, the strength of the link can be demonstrated by determining the correlation between the mean scores from the four groups of professionals. A non-parametric correlation test (Kendall's tau correlation coefficient) was adopted. The Kendall's tau ranges between -1 to +1 for negative and positive correlations correspondingly. The Kendall's correlation coefficients between the four groups of professionals are displayed in Table 2 below. 
Table 2 Kendall's tau Correlation Coefficient matrix

\begin{tabular}{cllllll}
\hline \multicolumn{2}{c}{ Mean scores } & All participants & Engineers & Contractors & Owners & Supervisors \\
\hline All participants & Coefficient & 1 & & & & \\
& Sig.(2-tailed) & & & & & \\
\multirow{2}{*}{ Engineers } & Coefficient & 0.765 & 1 & & & \\
& Sig.(2-tailed) & $0.000^{* *}$ & & & & \\
Contractors & Coefficient & 0.699 & 0.728 & 1 & & \\
& Sig.(2-tailed) & $0.000^{* *}$ & $0.000^{* *}$ & & & \\
Owners & Coefficient & 0.647 & 0.639 & 0.599 & 1 & \\
& Sig.(2-tailed) & $0.000^{* *}$ & $0.000^{* *}$ & $0.000^{* *}$ & & \\
Supervisors & Coefficient & 0.756 & 0.784 & 0.736 & 0.741 & 1 \\
& Sig.(2-tailed) & $0.000^{* *}$ & $0.000^{* *}$ & $0.000^{* *}$ & $0.000^{* *}$ & \\
Factors & $\mathrm{N}$ & 24 & 24 & 24 & 24 & 24 \\
\hline
\end{tabular}

Source: Authors own compilation

Table 2 shows that the correlated mean scores for various quality performance factors from the four groups of professionals. The highest correlation was between the mean scores of engineers and the mean scores supervisors $(0.784)$, and the lowest correlation was between the mean scores of owners and the mean scores of contractors $(0.599)$.

The Null Hypothesis $\left(\mathrm{H}_{0}\right)$ suggesting that "there is no significant link existing between the opinions of different groups of professionals in respect to the comparative importance of the quality performance factors" was rejected. There exists a solid link amid the professional's view on factors considered to be important in guaranteeing quality performance of state financed road construction projects. Altman and Bland (2017)was of the opinion that the agreed technique for measurement for two or more variables can be incorrectly connected to the correlation between the variables. A correlation with high coefficient does not depict strong agreement between the data that is being studied. A Kruskal Wallis test was carefully chosen to confirm agreement in views of individual groups. In this examination the data are ordered by ranking them from lowest to highest and assigning them (the integer values from 1 to the sample size).

Gergerlioğlu and McGee (2017)expresses that the Kruskal Walli’s test is measured as per equation;

$$
G=\left(\frac{12}{R(R+1)} \sum_{m-1}^{u} \frac{V_{m^{2}}}{s_{m}}\right)-3(R+1)
$$

Such that, $G$ is the Kruskal Walli's test, $u$ signifies the number of comparison groups, $R$ represents the total sample size, $s_{m}$ is the sample size in the $m^{\text {th }}$ group and $V_{\mathrm{m}}$ is the totality of the ranks in the $m^{\text {th }}$ group.

The null hypothesis $\left(\mathrm{H}_{\mathrm{o}}\right)$ stipulate that "there is no significant difference between the mean scores from the group of professionals" while the alternate hypothesis $\left(\mathrm{H}_{1}\right)$ stipulate "there is a significant difference between the mean scores from the groups of professionals". The outcome is that when the measured value of the KruskalWallis test is less than the critical chi-square value, then the null hypothesis is accepted suggesting that the sample emanates from the same population".

Data in this study encompassed four groups, the value for $u$ is equals to5 (mean scores for all participants, engineers, contractors, owners and supervisors) at alpha equals 0.01 with the degree of freedom at 3 . The total sample size was 120 and each group had 24 mean scores for each independent quality performance factor. The results are displayed in Table 3.

Table 3. Kruskal Walli's test data

\begin{tabular}{lr}
\multicolumn{1}{c}{ Data Description } & Obtained values \\
\hline Total sample size (R) & 120 \\
Sample size in each group (s) & 24 \\
Kruskal-Wallis value calculated & 9.7521 \\
Chi-square critical & 11.5478 \\
$p$ - value & 0.01542 \\
\hline
\end{tabular}

From Table 3 the calculated Kruskal Walli’s value (9.7521) is less than the critical value Chi Square (11.5478) Hence the null hypothesis is accepted. Analytically, the results imply that the mean scores for all five groups agree strongly.

\subsection{Relationship between Quality Performance and Critical Factors}

The study examined the data to find out if the possibility of coming out with an empirical mathematical model with the ability of predicting quality performance at given critical factors. It is presumed that there could be a linear relationship between the quality performance (dependent variable) and the critical performance factors (independent variables). Investigation was made to ascertain if the observed critical quality performance factors 
are related to the project performance.

The identified critical factors were; (i) financing processes of the project, (ii) issues on health and safety, (iii) project managers skills and knowledge, (iv) profitability of contractors, and (v) experiences of the contractor in the industry. These factors were the five major critical factors that had a direct impact on quality performance of the project (see Table 1).

The five major critical factors affecting the quality performance in the road construction industry were used in the analysis to determine whether there exists a linear relationship between project quality performance (dependent variable) and the critical quality performance factors (independent variables). Having verified and confirmed the assumptions of multiple linear regression models, the study data are further adopted to develop the multiple linear regression model of the following form;

$P Q P=\beta_{0}+\beta_{1} F P+\beta_{2} I H S+\beta_{3} P S K+\beta_{4} P C+\beta_{5} E C+\mu$

Such that $\beta_{0}$ represents the constant term of the model, $\beta_{1}$ to $\beta_{5}$ are coefficients of independent variables and $\mu$ signifies the error term. The terms PQP refers to project quality performance a dependent variable, where as independent variables are FP, IHS, PSK, PC and EC. The terms FP refers to financing processes of the project, IHSdenotesissues on health and safety, PSK signifies project managers skills and knowledge, PC refers to profitability of contractors and EC means experiences of the contractor in the industry.

The project quality performance variable (PQP) was regressed against the five major critical quality performance factors in the multiple linear regression model shown in equation. The experiences of the contractor in the industry (EC) was considered as a dummy variable coded as 0 or 1 . At preparation phase of the project, the experiences of the contractor are moderately less important in comparison to the other factors. At this phase the experiences of the contractor factor are coded as zero (0). During project execution however, experiences of the contractor are far important hence the experiences of the contractor factor in the model are coded as one (1).

Results for the multiple linear regression model discussed above are presented in the Table 4, Table 4. Regression Coefficient Values

\begin{tabular}{|c|c|c|c|c|c|}
\hline \multirow[b]{2}{*}{ Model } & \multicolumn{2}{|c|}{$\begin{array}{l}\text { Unstandardized } \\
\text { coefficients }\end{array}$} & \multirow{2}{*}{$\begin{array}{c}\text { Standardized } \\
\text { coefficients }\end{array}$} & \multirow[b]{2}{*}{$t$} & \multirow[b]{2}{*}{ Sig. } \\
\hline & Beta & Std. Error & & & \\
\hline (Constant) & $(0.012)$ & 0.717 & & $(0.028)$ & 0.866 \\
\hline Financing processes of the project & 1.899 & 0.154 & 0.213 & 5.487 & 0.000 \\
\hline Issues on health and safety & 1.266 & 0.187 & 0.241 & 6.821 & 0.000 \\
\hline Project managers skills and knowledge & 1.217 & 0.150 & 0.311 & 8.826 & 0.000 \\
\hline Profitability of contractors & 1.153 & 0.137 & 0.284 & 7.275 & 0.000 \\
\hline Experiences of the contractor in the industry & 1.214 & 0.134 & 0.329 & 8.951 & 0.000 \\
\hline
\end{tabular}

Table 5 contains the regression coefficients values. Using the data in Table 5 the project quality performance model can be presented as;

$\mathrm{PQP}=-0.012+1.899 \mathrm{FP}+1.266 \mathrm{IHS}+1.217 \mathrm{PSK}+1.153 \mathrm{PC}+1.214 \mathrm{EC}$

The first data for un-standardized coefficients is the multiple linear regression constant (-0.012) with an error of 0.717 and a $p$-value of 0.866 . The regression coefficient is not statistically significant. The constant is the predicted value when all independent factors are set to zero. Di Lullo, Gemechu, Oni, and Kumar (2019) observed that this constant is clearly meaningless and one should not even try to give it a meaning. There should be no project quality performance if all quality performance factors are not considered at all. The constant term serves as a tool for any bias that is not accounted for by the terms in the model. The role of the regression model is to minimize residuals between the observed and predicted data.

The other un-standardized data are the coefficients to the regression model. The coefficient for project financing processes is 1.899 with a $p$-value of 0.000 , coefficient for issues on health and safety is 1.266 with a $p$ value of 0.000 , coefficient for project managers skills and knowledge is 1.217 with a $p$-value of 0.000 , coefficient for profitability of contractors is 1.153 with a $p$-value of 0.000 , and the coefficient for experiences of the contractor in the industry is 1.214 with a $p$-value of 0.000 . All coefficients are statistically significant. The model was considered to be statistically significant.

\section{Discussion of Results}

\subsection{Critical factors that imped quality performance of project}

The main objective of this study was to ascertain the critical factors that imped quality performance of state financed road construction project in Botswana. The study espoused a questionnaire that was close-ended to garner responses from individuals involved in supervision, planning and implementation of state financed road construction projects. From their responses the study discovered that the five (5) top most critical factors that had a direct influence on the quality performance of state financed construction projects in Botswana. The recognized five (5) critical factors are discussed as follows; 
a) Financing processes of the project

The financing processes was the highest ranked quality performance factor among all participants. Findings from the study conforms with the study of Smith and Smith (2019), who posited that project financing processes comprise of generating funds on a meager recourse for the purposes of developing a large capital-intensive project. From the commencement phase, planning phase, execution phase and commissioning phase are all vital phases that need a strong financing process. Furthermore, He, Wang, Chan, Li, and Chen (2019) affirms the outcome and demonstrates that the dearth of sustained financing processes can lead to project unit cost differences, time disparity, project net present values inconsistency, changes in project functionality and stakeholder's displeasure. Other researchers (Amusan, Dosunmu, \& Joshua, 2017; Keng, Mansor, \& Ching, 2018) also concurred with the findings. There will be a compromise on quality, project delays and legal disputes due to delays of payments to the contractor, cost overruns when there is lack of project financing arrangement.

b) Issues on health and safety

The issues on health and safety was ranked second as a major factor impeding quality performance factors in the construction industry. According to Umeokafor (2017), the construction industry is concurrently recognized as a major economic force and one of the most hazardous industries. Accidents not only result inconsiderable pain and suffering but marginalize productivity, quality, time and negatively affect the environment and consequently add to the cost of construction. Considering the contrary effects of accidents, construction health and safety management is of sincere apprehension to all stakeholders in the construction industry. In most emerging economies, health and safety attention in construction project delivery is not given precedence, and employment of safety measures during construction is considered a burden (Suresh, Oduoza, \& Renukappa, 2018). Health and safety have been identified as a parameter which should be used along with the traditional parameters: cost, quality and time, to measure the success of projects. The reasons for considering safety and health are human factor, legislation and financial issues(Udo, Usip, \& Asuquo, 2016).

c) Project managers skills and knowledge

Skills and knowledge of managers ranked as the third major critical factor impeding the quality of project management in Botswana's road construction industry. Although a project could have a well-conceived plan of execution with enough funding, resource specialists, and vastly knowledgeable consultants, if the efforts of all the participants are not managed and coordinated well, the project could suffer deficit in the budget or fail to meet the timetable(Bello, 2018). The more intricate the project, the more the general management function becomes critical. It would be unimaginable in the construction industry to conduct a construction project deprived of a project manager. During economic downturns, however, many project managers are sacked owing to termination of projects (Danforth, Weidman, \& Farnsworth, 2017). However, another main motive for project manager downsizings is not seeing the value a project manager adds to the project. A lot of businesses have described project manager choice standards imprecisely and often concentrate more on fit into the organization than capability for the post.

There is therefore the need for project managers to possess the required outstanding skills and qualities that will enable them have a smooth amalgamation with employees, in addition to attaining a noteworthy level of respect (Kerzner, 2017). Such skills are categorized into four groups namely; communication, managerial, relationship qualities, and personal qualities.

d) Profitability of contractors

Profitability of contractors was also seen to be a major factor affecting project quality performance in the road construction industry (Adjei, Fugar, Adinyira, Edwards, \& Pärn, 2018).Constructors turn overranges have long been a contentious subject in the industry, with many mentioning them as a factor in the indeterminate financial milieu facing even the largest, most-established businesses.

Construction turnover ranges are the lowest of any industry apart from for retailing. An entire congregation of explanations explain the financial breakability of contracting businesses, particularly the highly disjointed characteristic of the sector where there is inadequate training and modernization leading to low productivity(Witter, Bertone, Dale, \& Jowett, 2019). The sector is also highly recurring making companies bid at too low a price, with the hope they will make enough income on a contract via variations (Harvey, 2016).

e) Experiences of the contractor in the industry

The quality performance factor, project manager knowledge and skills ranked fifth in the study. The study referred to the project manager as the head of the project supervision team. Participants considered that such person should have adequate knowledge, skills and experience in the project. Project manager manages project data and people. As a leader must be able to establish direction for the future, communicate the project data and forge an aligned team work spirit.

Scholars (Arditi, Nayak, \& Damci, 2017; Bagaya \& Song, 2016; Santoso \& Soeng, 2016) are in agreement with the findings and they noted that poor site management and supervision were the major reasons for project delays. Poor site management and supervision could be attributed to lack of leadership skills or managerial capability of the project manager. The scholars urged that project managers should have outstanding technical 
skills and interpersonal skills.

Contractors experience in construction industry was the second highly ranked quality performance factors. Participants perceived that contractor's knowledge plays a very important part in accomplishing quality performance of the projects. Contractors knowledge combines both experience of its staff and outstanding involvement of the firm in construction projects.

The Botswanan Construction Industry Policy (2003) concur with the findings and highlights on the need of having knowledgeable contractors in construction projects. Lack of experienced contractors in the state construction projects is one of the challenges put forward by the policy. The policy directs the state to develop capabilities of local contractors through training, allocating more work opportunities and resources in terms of finance. Study by Ogutu and Muturi (2017), as well is in agreement with these findings as it shows that elements of quality project output include; workmanship, teamwork, cost control, timely project completion, proper resource management, availability of experienced and skilled personnel, competitive tendering and continuous improvement. All these elements can be managed and properly controlled by experienced contractors.

Furthermore, Vanneste (2019) and Oguntona and Aigbavboa (2019) support these findings and comment that the success of construction projects depended on the experience of the contractor and capability of the contractor's project manager. The project manager manages and directs the project, based on a full understanding of the requirements and the vision. Inadequate experience and skills for contractors led to; lack of understanding tendering process and procurement policies, ignorance to develop business plans, inability to secure work, inadequate operational and managerial skills amongst contractors, cheapening and lack of understanding of the general conditions of contracts. Based on the result it is claimed that contracting arrangement that comprises the selection of experienced contractors plays an imperative role in successful project execution.

\subsection{Project Quality Performance and Critical Performance Factors Relationship}

The study also examined the relationship between quality performance and the critical quality performance factors that affect performance of state financed construction project in Botswana. A model (equation 6) displaying positive linear relationship between the independent variable and the dependent variable was developed. OseiKyei et al. (2017) and Jin (2018) had comparable finding on the linear relationship between project success and various performance factors.

The positive linear relationship in the model infers that agencies overseeing state construction projects should adopt strategies that will ensure the critical performance factors are the well-thought-out phase of the project planning. Quality effectiveness of state construction projects could be guaranteed once these factors are made to be the pivotal points by all financiers, employers, planners and all other stakeholders involved in project planning, execution, commissioning and maintenance.

\section{Conclusion and Recommendations}

The main objective of this study was an evaluation of critical factors impeding quality performance of state financed road construction projects in Botswana. Findings from the study established that quality performance of state financed road construction projects in Botswana is impacted by 5 major critical quality performance factors as suggested by the participants namely; financing processes of the project, issues on health and safety, project managers skills and knowledge, and profitability of contractors

It was also established that there is a positive multiple linear relationship between critical quality performance factor and the quality performance of state financed road construction projects in Botswana.

The study findings demonstrate that quality performance of construction projects could be achieved if problems discussed in the study are well thought at the project commencement. Disregarding these problems renders snags in achieving targeted quality of road construction works. A tool has provided by the findings of this research to policy makers and planners who wish to participate into new construction projects in general. The critical factors for quality performance, forms a significant knowledge base for attaining quality performance in road construction projects. The traditional project success factors of time, cost and schedule can no longer stand alone; they strongly need to be augmented by the findings discussed in this study.

\section{Acknowledgments}

This work was supported by the National Natural Science Foundation of China (Nos. 71971100,71671078,71501084); Social Science Fund of Jiangsu Province (19GLB005,19GLB018) ; The Key Project of Philosophy and Social Science Research in Colleges and Universities in Jiangsu Province (2018SJZDI052); sponsored by Qing Lan Project of Jiangsu Province; Youth Backbone Teacher Training Project of Jiangsu University.

\section{References}

Abdalla, A., \& Otieno, M. (2017). Determinants of implementation of county government projects: A case of 
infrastructural projects in Kilifi County, Kenya. International Journal of Latest Research in Engineering and Technology, 3(9), 108-118.

Adjei, E. A., Fugar, F. D., Adinyira, E., Edwards, D. J., \& Pärn, E. (2018). Exploring the significant cash flow factors influencing building projects profitability in Ghana. International Journal of Construction Engineering and Management, 7(1), 35-46.

Akali, T., \& Sakaja, Y. (2018). Influence of Contractors' Financial Capacity on Performance of Road Construction in Kakamega County. American Scientific Research Journal for Engineering, Technology, and Sciences (ASRJETS), 46(1), 34-50.

Al-Hazim, N., Salem, Z. A., \& Ahmad, H. (2017). Delay and cost overrun in infrastructure projects in Jordan. Procedia Engineering, 182, 18-24.

Alamgir, M., Campbell, M. J., Sloan, S., Goosem, M., Clements, G. R., Mahmoud, M. I., \& Laurance, W. F. (2017). Economic, socio-political and environmental risks of road development in the tropics. Current Biology, 27(20), R1130-R1140.

Altman, D. G., \& Bland, J. M. (2017). Assessing agreement between methods of measurement. Clinical chemistry, 63(10), 1653-1654.

Amusan, L. M., Dosunmu, D., \& Joshua, O. (2017). Cost and time performance information of building projects in developing economy. International journal of mechanical engineering and technology (IJMET), 8(10), 918-927.

Arditi, D., Nayak, S., \& Damci, A. (2017). Effect of organizational culture on delay in construction. International Journal of Project Management, 35(2), 136-147.

Bagaya, O., \& Song, J. (2016). Empirical study of factors influencing schedule delays of public construction projects in Burkina Faso. Journal of Management in Engineering, 32(5), 05016014.

Bello, W. (2018). Project performance diagnostics: a model for assessing construction project performance in Nigeria. University of Salford, Manchester.

Chen, H. L., Chen, W. T., \& Lin, Y. L. (2016). Earned value project management: Improving the predictive power of planned value. International Journal of Project Management, 34(1), 22-29.

Danforth, E. M., Weidman, J. E., \& Farnsworth, C. B. (2017). Strategies employed and lessons learned by commercial construction companies during economic recession and recovery. Journal of Construction Engineering and Management, 143(7), 04017027.

Davis, K. (2017). An empirical investigation into different stakeholder groups perception of project success. International Journal of Project Management, 35(4), 604-617.

Di Lullo, G., Gemechu, E., Oni, A. O., \& Kumar, A. (2019). Extending sensitivity analysis using regression to effectively disseminate life cycle assessment results. The International Journal of Life Cycle Assessment, 118.

Dong, H., Zhang, J., \& Lv, S. (2016). Engineering Project Real-time Objective Monitor Based on Grid Management and Buffer Analysis. The Open Civil Engineering Journal, 10(1).

Fagbenle, O. I., Joshua, O., Afolabi, A., Ojelabi, R. A., Fagbenle, O., Fagbenle, A. O., \& Akomolafe, M. (2018). Cost Management Practice of Construction Firms and Its Influencing Factors: Lessons from Southwestern Nigeria.

Gergerlioğlu, U., \& McGee, R. W. (2017). University Students' Attitudes Towards Tax Consciousness: A Case Study of the Faculty of Economics at Istanbul University. Researcher: Social Science Studies, 5(10).

Harvey, J. (2016). Urban land economics: Macmillan International Higher Education.

He, Q., Wang, T., Chan, A. P., Li, H., \& Chen, Y. (2019). Identifying the gaps in project success research: A mixed bibliographic and bibliometric analysis. Engineering, Construction and Architectural Management.

Heravi, G., \& Mohammadian, M. (2019). Investigating cost overruns and delay in urban construction projects in Iran. International Journal of Construction Management, 1-11.

Jin, M. E. E. (2018). Factors Affecting Growth of Construction Organizations in Nairobi. United States International University-Africa.

Keng, T. C., Mansor, N., \& Ching, Y. K. (2018). An Exploration of Cost Overrun in Building Construction Projects. Global Business and Management Research, 10(3), 638.

Kerzner, H. (2017). Project management: a systems approach to planning, scheduling, and controlling: John Wiley \& Sons.

Kerzner, H. (2019). Using the project management maturity model: strategic planning for project management: Wiley.

Kumar, S., Duhan, M., \& Haleem, A. (2016). Evaluation of factors important to enhance productivity. Cogent Engineering, 3(1), 1145043.

Lishner, I., \& Shtub, A. (2019). Measuring the success of Lean and Agile projects: Are cost, time, scope and quality equally important? The Journal of Modern Project Management, 7(1).

Mishmish, M., \& El-Sayegh, S. M. (2018). Causes of claims in road construction projects in the UAE. 
International Journal of Construction Management, 18(1), 26-33.

Naoum, S. G., \& Egbu, C. (2016). Modern selection criteria for procurement methods in construction: A state-ofthe-art literature review and a survey. International Journal of Managing Projects in Business, 9(2), 309-336.

Nasaruddin, N., \& Rahman, I. (2017). Overall Significance's Rank of Leadership Factors Amongst Critical Success Factors for Construction Projects. Paper presented at the Global Civil Engineering Conference.

Ngwai, F., Simba, F., \& Oyoo, J. (2019). Influence of project management practices on construction cost control of projects in Mombasa County. The Strategic Journal of Business \& Change Management, 6(3), 314-330.

Oguntona, O. A., \& Aigbavboa, C. O. (2019). Biomimicry Approaches for Innovative Sustainable Solutions in the Construction Industry. Innovative Production And Construction: Transforming Construction Through Emerging Technologies, 335.

Ogutu, B. O., \& Muturi, W. (2017). Factors influencing successful completion of road construction projects in Kenya: The Case of Kisumu County. International Journal of Economics, Commerce and Management, 5(6), 657-698.

Oke, A., Aigbavboa, C., \& Dlamini, E. (2017). Factors Affecting Quality of Construction Projects in Swazilland. Paper presented at the The Ninth International Conference on Construction in the 21st Century (CITC-9)" Revolutionizing the Architecture, Engineering and Construction Industry through Leadership, Collaboration and Technology". Marcch 5th-7th 2017.

Olawumi, T. O., \& Chan, D. W. (2019). Critical success factors for implementing building information modeling and sustainability practices in construction projects: A Delphi survey. Sustainable Development.

Osei-Kyei, R., Chan, A. P., Javed, A. A., \& Ameyaw, E. E. (2017). Critical success criteria for public-private partnership projects: international experts' opinion. International Journal of Strategic Property Management, 21(1), 87-100.

Padalkar, M., \& Gopinath, S. (2016). Six decades of project management research: Thematic trends and future opportunities. International Journal of Project Management, 34(7), 1305-1321.

Rahmani, F., Maqsood, T., \& Khalfan, M. (2017). An overview of construction procurement methods in Australia. Engineering, Construction and Architectural Management, 24(4), 593-609.

Raphael, G., \& Phillip, A. W. (2016). An Assessment of Critical Factors Affecting Quality Performance of Government Financed Construction Projects: Evidence from Tanzania. Bus. Manage. Strategy, 7, 82-101.

Rezvani, A., Chang, A., Wiewiora, A., Ashkanasy, N. M., Jordan, P. J., \& Zolin, R. (2016). Manager emotional intelligence and project success: The mediating role of job satisfaction and trust. International Journal of Project Management, 34(7), 1112-1122.

Rumane, A. R. (2017). Quality management in construction projects: CRC Press.

Santoso, D. S., \& Soeng, S. (2016). Analyzing delays of road construction projects in Cambodia: Causes and effects. Journal of Management in Engineering, 32(6), 05016020.

Sfakianaki, E. (2019). Critical success factors for sustainable construction: a literature review. Management of Environmental Quality: An International Journal, 30(1), 176-196.

Siati, A., Nzulwa, J., \& Kwena, R. (2019). Determinants of completion of building construction projects in Kenya: A case study of Nairobi County. The Strategic Journal of Business \& Change Management, 6(2), 702-716.

Smith, J. K., \& Smith, R. L. (2019). Entrepreneurial Finance: Venture Capital, Deal Structure \& Valuation: Stanford University Press.

Suresh, S., Oduoza, C., \& Renukappa, S. (2018). Leadership Initiatives for Health and Safety Risk Management Systems in a Small Construction Company: A Case Study Risk Management Treatise for Engineering Practitioners: IntechOpen.

Udo, U. E., Usip, E. E., \& Asuquo, C. F. (2016). Effect of lack of adequate attention to safety measures on construction sites in Akwa Ibom State, Nigeria. Journal of Earth Sciences and Geotechnical Engineering, 6(1), 113-121.

Ugo, P. D. (2017). Project Quality Management Performance: An Insight to Sustainable Development Initiatives in Oil and Gas Host Communities. J. Mgmt. \& Sustainability, 7, 76.

Umeokafor, N. (2017). An appraisal of the barriers to client involvement in health and safety in Nigeria's construction industry. Journal of Engineering, Design and Technology, 15(4), 471-487.

Vanneste, P. (2019). Understand and find solutions to the main cause of disputes in construction: Project manager's failures to understand or comply with their contractual obligations1, 2.

Vaske, J. J., Beaman, J., \& Sponarski, C. C. (2017). Rethinking internal consistency in Cronbach's alpha. Leisure Sciences, 39(2), 163-173.

Witter, S., Bertone, M. P., Dale, E., \& Jowett, M. (2019). Health financing in fragile and conflict-affected situations: A review of the evidence. 